\title{
THE DIVERSITY PERCEPTION AND THE ATTITUDES OF EMPLOYEES: A STUDY ON HUMAN RESOURCE PROFESSIONALS AND HOTEL WORKERS
}

\author{
Prof. Dr.Melek V. Tüz \\ Uludağ Üniversitesi \\ İktisadi ve İdari Bilimler Fakültes
}

\author{
Doç. Dr. Murat Gïmuiş \\ Çanakkale Onsekiz Mart Üniversitesi \\ Turizm İşletmeciliği ve Otelcilik Meslek Yüksekokulu
}

\section{Çalışanların Farklılık Algı ve Tutumları: Insan Kaynakları Profesyonellerine ve Otel Çalışanlarına Yönelik Bir Araştırma \\ Özet}

Küreselleșmeye bağlı olarak, sosyal ortamlarda, özel olarak işyerinde farklılık konusu çeșitli firsatları ve tehditleri taşımaktadır. Bu bağlamda, mevcut çalışmanın amacı, işletmelerde farklılık algılarını ve farklılık iklimini belirlemektir. Bu sınırlama içerisinde, çalışmada bireyin farklılıktan ne anladığı sorusuna yanıt aranmış olup, iş gruplarında ve iş dışındaki genel sosyal ortamlarda önemli farklılık faktörleri sorgulanmıştır. Insanlar, benzer insanların oluşturduğu homojen grupların ve benzer olmayan insanların oluşturduğu heterojen (farklılık içeren) grupların avantajlarına ve dezavantajlarına nasıl bakmaktadırlar? Genel farklılık algılaması nedir? Bu sorular ulusal düzlemde test edilmiştir, zira farklılık konusunda yapılan araştırmaların büyük çoğunluğu, kültürlerarası ve uluslararası düzlemde yapılmaktadır. Bu araştırmanın özgünlüğü, çeşitli alt kültürlerin mevcut olduğu bir kültür içinde genel farklılık algısının incelenmesidir. Sonuçlar, karşılaştırılan gruplar arasında anlamlı farklılıklar olduğunu göstermektedir.

Anahtar Kelimeler: İşyeri farklılı̆̆ı, farklılık algısı, gruplarda farklılık, sosyal ortam farklılığı, insan kaynakları profesyonelleri ve otel çalışanları.

\begin{abstract}
Owing to globalization, the issue of diversity in social settings, particularly in the workplace presents several challenges and threats. In this context, the aim of the present study is to identify perceptions of diversity and the diversity climate within business organizations. Within this scope, factors defining diversity that are important in group and social settings are considered and the answer to the question "what do the individuals understand from diversity?" is sought. How do people view the advantages and disadvantages of homogeneous and heterogeneous (diverse) groups? What is the general perception of diversity? These questions were tested in a domestic setting, because the majority of research into diversity issues is applied to intercultural and international settings. The originality of this research is that it examines the general perception of diversity within one culture in which various sub-cultures exist. The results show significant differences among investigated groups. For instance, higher education level, managerial role, and experience abroad lead to a higher positive perception of diversity. Amongst others, culture and language are two prominent diversity factors.
\end{abstract}

Keywords: Workplace diversity, diversity perception, diversity in groups, diversity in social setting. 


\section{The Diversity Perception and the Attitudes of Employees: A Study on Human Resource Professionals and Hotel Workers}

\section{Introduction}

The issue of diversity is of great importance in many countries and international organizations such as the United Nations and the European Union (http://web20.s112.typo3server.com, http://www.un.org). Respect for diverse groups, cultures, minorities, and new multicultural societies are just a few of the concepts relevant to diversity, which now exists on a global scale. According to Kymlicka (cited in Bal1, 2001:195), there are 600 groups of living languages and 5000 ethnic groups in the 184 countries of the world. It is assumed that there are 47 ethnic groups in Turkey alone (Bal1, 2001: 200).

Diversity in business organizations is also a current issue. Workplace diversity and its management have been prominent topics in recent years (Cox, 1991; Barry/Bateman, 1996; Knouse/Dansby, 1999; De Meuse/Hostager, 2001; Triandis, 2003). The American literature on management is rife with advice to increase workforce diversity as a way of enhancing work group effectiveness (Ely/Thomas, 2001: 229). North America is where most of the diversity research has been conducted (Hicks-Clarke/Iles, 2000). The primary focus of research on diversity has been the effectiveness and outcomes of workforce diversity in organizations (Milliken/Martins, 1996). Owing to rapid globalization, extended markets and changes in demographic measures, the merit of evaluating and managing diversity has attracted increasing attention, since different work environments require diverse workforces (Joplin/Daus, 1997; Strauss/Connerley/Ammermann, 2003). Estimation reports and studies have revealed that ethnic, racial and gender demographics in the labor force of several countries are steadily increasing (Kossek/Zonia, 1993; Mor 
Barak/Cherin/Berkman, 1998; Hicks-Clarke/Iles, 2000; Kersten, 2000; O’Flynn et al., 2001).

\section{Literature Review}

\section{Conceptual Overview}

The term diversity is used in diversity studies in a broader sense concerning human differences. It is used to describe all types of dimensions of an organization's employees, such as role, function and personality (HicksClarke/Iles, 2000). Age, gender, sexual orientation, social class, culture, ethnicity, disability, education, beliefs, experiences, and race are the primary elements that make individuals different from another one (Joplin/Daus, 1997; Hicks-Clarke/Iles, 2000; Kersten, 2000; Triandis, 2003). Diversity can also be categorized as personal or organizational. Personal differences can be appearance-related, such as skin color, race, gender, etc., or internal, such as values, beliefs, etc. Organizational differences are considered to be tenure, position and technical skills. This classification is congruent with intergroup theory, which defines groups as identity groups or organizational groups (Alderfer/Smith, 1982; Kossek/Zonia, 1993).

\section{Advantages and Disadvantages of Diversity}

The underlying assumption of attaching importance to diversity and diversity management is that diversity will bring positive outcomes for an organization. Diversity is important in idea generation, growth, learning, image, human resources, and discrimination law (Hon/Brunner, 2000; Friedman/ Amoo, 2002). In other words, diversity can add value if it is managed effectively (Milliken/Martins, 1996; Knouse/Dansby, 1999). A diverse workforce can produce higher quality work because of its broader perspectives and ideas put forward for problem-solving. Understanding the different demands and expectations of diversified markets, group decision-making, group interaction, and innovation are some of the several expected outcomes for an organization (Knouse/Dansby, 1999: 486-7). Fostering and facilitating a positive diversity climate is considered a business imperative and strategic leadership focus in organizations, since it offers a competitive edge domestically and internationally (Joplin/Daus, 1997; Combs, 2002).

People who view diversity positively in the workplace believe that individual differences are positive. Diversity can be a source of learning and creativity; interactions with people from different backgrounds are welcomed; it is an opportunity for personal promotion and organizational profitability (De 
Meuse/Hostager, 2001: 34). The benefits of workplace diversity are mainly linked to better decision-making, greater creativity and innovation, and better service for foreign and ethnic groups in terms of marketing and economic distribution of opportunities (Cox, 1991). A firm may achieve a flexible strategic fit more easily if it has a diverse workforce (Laursen/Mahnke/VejrupHansen, 2004).

On the other hand, workplace diversity leads to disadvantages such as high turnover rates, interpersonal conflicts and communication breakdown (Cox, 1991: 34). According to research, interpersonal similarity facilitates communication, improves trust and enhances reciprocal relations (Mor Barak/ Cherin/Berkman, 1998: 88).

Opposition to diversity in the workplace arises from a fear of difference, having stereotyped attitudes, a belief that diversity initiatives are unfair, and a belief that diversity is a threat to career development, performance development, and profitability of the firm (Cox, 1993; De Meuse/Hostager, 2001). Research findings have identified a decrease in communication and cohesiveness with increasing demographic heterogeneity between groups (Cox, 1991: 36). However, other studies revealed that the diversity of demographic and physical characteristics in heterogeneous groups decreases after they start working together because of acquaintance between more tenured members and new members (Jackson et al., 1991). At the beginning, a homogeneous group performs better, but with the experience of working together, heterogeneous group performs better in terms of problem-solving and innovation (Knouse/ Dansby, 1999: 492). It has been argued that the optimal ratios for minority status are between $10 \%$ and $20 \%$ by researchers such as Davis (psychological minority phenomenon), Kanter (critical mass) and Izraeli (representative minority) several decades ago (Knouse/Dansby, 1999: 487-8). Optimal ratios of $11-30 \%$ for diversity and $31-50 \%$ women seem to lead to group effectiveness (Knouse/Dansby, 1999: 491). Indeed, diversity implementation in an organization can threaten the positions of privileged groups such as men, Caucasians, and major cultural groups (Kossek/Zonia, 1993: 63-4). Thus, diversity leadership in a organizations is a strategic imperative (Dreachslin/ Saunders, 1999) because it is a response to demographic shifts and changing attitudes among workforce and target groups. Studies have revealed that more authoritarian individuals are likely to have negative attitudes toward diversity and agreeableness is strongly related to attitudes toward diversity (Strauss/ Connerley/Ammermann, 2003: 46). Diversity thus seems a crucial consideration in what to manage and who to employ in an organization. Diversity management, meaning systematic management of workplace diversity, is seen as a relational rather than a structural model. Thus, without 
structural equity and accountability in companies, communication, teamwork, training, organizational cohesion, conformity, compliance and the importance of the whole organization versus its parts depend on diversity (Kersten, 2000: 243-6).

The elements identified are generally factors that are included in organizational demographic characteristics in Pfeffer's model and are powerful determinants of perceptions of similarity and person-environment fit (Jackson et al., 1991). These factors influence many behavioral patterns, including communication, promotion, job transfer and turnover, according to Pfeffer (Jackson et al., 1991). Team heterogeneity was also found to be a relatively strong predictor of team turnover rates in the study by Jackson et al (1991). Team heterogeneity may challenge the status quo and thus can irritate dominant organizational actors (e.g., white males) and reveal negative reactions among them (Tsui/Egan/O'Reilly, 1992). The focus of the present study is the workplace setting. Since work is carried out by groups within organizations, the impact of diversity in groups, diversity views and perceptions of individuals are crucial in determining whether diversity affects organizational goals. Kossek and Zonia (1993) reported a strong relation between diversity climate and groups rather than organizational units, and that gender heterogeneity is significant in valuing diversity. Moreover, as the group size increased, so did communication and coordination problems. In other words, larger teams tend to be less cohesive owing to higher levels of heterogeneity (Jackson et al., 1991). As heterogeneity increases, absenteeism and turnover increase among males (Friedman/Amoo, 2002).

\section{Exploiting Workplace Diversity}

The issue of diversity is a double-edged sword. Organizations can benefit from diversity or it can distort the climate and can lead to conflicts. To overcome problems arising from diversity, solutions such as changing the organizational culture to value diversity and targeting organizational goals rather than individual needs have been suggested (Chatman et al., 1998). Thus, diversity leadership plays a crucial role in the success of diversity initiatives. Knowing at what stage the organization is on the intolerance-appreciation continuum is important before embarking on diversity initiatives (Joplin/Daus, 1997: 45). The idea that there is greater similarity than dissimilarity among humans (Gülgöz, 2005; Önen, 2006) can be a very useful starting point for promoting diversity. As Triandis (2003: 492-3) suggested, when developing good relationships in culturally diverse organizations where there is a need to 
decrease perceived dissimilarities and to increase similarities between "us" and "them", the following approaches can be used to promote diversity:

- Emphasize similarities,

- Train people to perceive the disadvantages of categorization,

- Train staff to re-categorize (emphasizing similarities),

- Make individuals of their ethnocentrism,

- Favor multiculturalism,

- Increase the use of superordinate goals,

- Train people to understand fundamental attribution errors (suppress stereotyping),

- Train individuals to use interpersonal rather than intergroup judgement, and

- Train staff to understand social dominance theory.

\section{Diversity Climate and Its Measurement in Organizations}

Intergroup relations are crucial in organizations and are influenced by power differences between groups in the organizational context (Alderfer/Smith, 1982). The organizational climate, generally perceived as the influence of the organizational atmosphere on employees' perceptions that ground behavior and attitudes (Schneider/Reicher, 1993), is an important parameter in assessing how people in the work environment feel and perceive the context. The organizational climate is a sign of the wellness of the work setting. It refers to the characteristics dominating the organization (Baran, 2000: 222). In particular, the diversity climate refers to the psychological perspective (Hicks-Clarke/Iles, 2000: 326) and influences affective outcomes, such as satisfaction and involvement, and achievement outcomes, such as opportunity, recognition and efficiency (Milliken/Martins, 1996; Bean et al., 2001). One mistake made by managers is to consider foreign cultures and ethnic subcultures in their homeland as if they were homogeneous (Cotte/Ratneshwar, 1999: 202). A diversity climate can be created by practices, procedures and rewards in the organization (Schneider/Gunnarson/Niles-Jolly, 1994: 18) and it can be evaluated in three dimensions, namely, in terms of individual, group and organizational factors (Cox, 1993; Bean et al., 2001).

Measuring attitudes toward diversity has not been the focus of much attention, although the issue of diversity itself has been widely addressed (De Meuse/Hostager, 2001). However, some instruments to evaluate workplace 
diversity have been developed. The Reaction to Diversity Inventory, developed by De Meuse and Hostager (2001), assesses the general reaction and perception of employees. This inventory is recommended if there are diversity practices or endeavor in the organization. Another instrument, the Diversity Perception Scale developed by Mor Barak et al. (1998), focuses on perceptions assuming that behavior is driven by perceptions of reality. It focuses on personal and organizational dimensions in a diversity climate and it is convenient for determining the overall diversity environment. A third instrument is the Attitudes Toward Diversity Scale of Montei et al. (1996) that comprises 30 items and focuses on co-workers, supervisors, hiring and promotion decisions (Strauss/Connerley/Ammermann, 2003: 40). A final instrument that should be mentioned is the Diversity Climate Survey developed by Robert Bean and Caroline Dillon in 2000 (Bean et al., 2001). This instrument includes 15 profile questions and 15 statements, with a 5-point Likert scale. Using three dimensions (individual, group and organizational), each with five items, information on how differences are perceived, how differences affect the work of individuals and teams, and how effectively diversity is managed is gathered. The instrument can identify affective and achievement outcomes (Bean et al., 2001).

\section{Aims and Objectives of the Research}

Several studies have addressed topics concerning diversity issues such as cultural differences (Sargut, 2001), discrimination and sexual harassment (Aslan/ Vasilyeva, 2003) in workplaces in Turkey; however, diversity itself has not been considered in a Turkish setting to any great extent and it's limited to the cultural aspects of diversity concepts (Usluata/Bal, 2007: 100). In recent times, diversity itself is getting more attention especially in social settings (Toprak et al, 2008; Gümüş, 2009). On the other hand, the discussion on diversity or "others" focuses on "others from different cultures and different countries than one's own". However, in perceiving others, social prejudices are critical, and thus diversity issues can be identified for "the same culture and country as one's own" (Gülgöz, 2005).

For this reason, the aim of the present study was to provide a means to determine diversity for both academic and practical approaches.

The basic questions to be answered within this study are as follows:

a) What diversity elements constitute a definition of diversity in Turkish work organizations? 
226• Ankara Üniversitesi SBF Dergisi • 65-2

b) What diversity elements are influential in the workplace setting (team composition)?

c) What diversity elements influence a person's social distance?

d) What are the advantages of a diverse team/group?

e) What are the disadvantages of a diverse team/group?

f) What are the advantages of a homogeneous team/group?

g) What is the overall level of diversity perception in Turkish workplaces?

\section{Methodology}

\section{Participants}

Two groups of participants were recruited for this study. One group of participants was individual members or volunteers of Peryon (The Association for Personnel Management in Turkey), an organization for human resources and personnel professionals. Institutional memberships (firms) were not included. There were 2500 individual members of Peryon in 2005, who were human resources professionals, specialists and academic staff (www.peryon.org.tr; www.wfpma.com/turkey.html; http://www.peryon.org.tr/ hakkimizda.asp) Questionnaire forms were delivered and sent to these professionals. A total of 245 forms were returned. Nine questionnaires were excluded because of a high number of unanswered items. Thus, 236 forms from Peryon were included in the analysis.

The second group of participants comprised managers and employees of hotels in Bursa, the fourth-largest city in Turkey. Data obtained from 130 participants were used.

Table 1: Descriptive characteristics of the groups.

\begin{tabular}{|l|l|r|r|}
\hline Variable & Sub-category & $\mathrm{n}$ & $\%$ \\
\hline \multirow{4}{*}{ Aroup } & Peryon & 236 & 64.5 \\
\cline { 2 - 4 } & Hotel & 130 & 35.5 \\
\hline \multirow{5}{*}{ Gender } & $\leq 25$ years & 77 & 21.0 \\
\cline { 2 - 4 } & $26-35$ years & 147 & 40.2 \\
\cline { 2 - 4 } & $36-45$ years & 104 & 28.4 \\
\cline { 2 - 4 } & 46-55 years & 29 & 7.9 \\
\cline { 2 - 4 } & $\geq 56$ years & 9 & 2.5 \\
\hline & Male & 231 & 63.1 \\
\cline { 2 - 4 } & Female & 135 & 36.9 \\
\hline
\end{tabular}




\begin{tabular}{|l|l|r|r|}
\hline Education level & Primary & 12 & 3.3 \\
\cline { 2 - 4 } & Secondary & 20 & 5.5 \\
\cline { 2 - 4 } & Lycee & 78 & 21.3 \\
\cline { 2 - 4 } & Undergraduate & 48 & 13.1 \\
\cline { 2 - 4 } & Graduate & 158 & 43.2 \\
\cline { 2 - 4 } & Postgraduate & 50 & 13.7 \\
\hline \multirow{5}{*}{ Position } & Manager & 171 & 46.7 \\
\cline { 2 - 4 } & Non-manager & 195 & 53.3 \\
\hline \multirow{5}{*}{ Experience abroad } & Experience & 149 & 40.7 \\
\cline { 2 - 4 } & No experience & 217 & 59.3 \\
\hline \multirow{5}{*}{ Nenure } & $<1$ year & 58 & 15.8 \\
\cline { 2 - 4 } & $1-3$ years & 111 & 30.3 \\
\cline { 2 - 4 } & $4-5$ years & 37 & 10.1 \\
\cline { 2 - 4 } & $\geq 6$ years & 160 & 43.7 \\
\hline \multirow{5}{*}{ Number of jobs } & First & 92 & 25.1 \\
\cline { 2 - 4 } & Second & 32.5 \\
\cline { 2 - 4 } & Third & 19.9 \\
\cline { 2 - 4 } & Fourth or more & 82.4 \\
\hline
\end{tabular}

In terms of the background profile of respondents, the majority were men $(63.1 \%)$ and more than half were not in a managerial position $(53.3 \%)$. The greatest numbers of subjects were in the age groups $26-35$ years $(40 \%)$ and $36-$ 45 years $(28.4 \%)$, followed by $\leq 25$ years $(21.0 \%)$. Some $43.2 \%$ of respondents held a university degree, and together with postgraduate degrees $(13.7 \%)$ and undergraduates (13.1\%) accounted for the majority of the subjects $(70.0 \%)$. Respondents with experience abroad amounted to $40.7 \%$. Individuals with more than 6 years of tenure were in the majority $(43.7 \%)$, whereas new members $(<1$ year) accounted for only $15.8 \%$ of the respondents. In terms of job changes to date, $32.5 \%$ were in their second job and $25.1 \%$ were in their first. No disabled persons responded to the questionnaire.

\section{Instrument}

The survey instrument applied to both study groups consisted of four parts and was prepared considering several instruments in the literature (Mor Barak/Cherin/ Berkman, 1998; Bean et al., 2001; De Meuse/Hostager, 2001). The first part consisted of 10 profile questions about the participants, namely, gender, position, experience abroad, age, education, tenure, number of job 
changes, and disability. In setting these profile questions, the literature on questioning personal and organization-related characteristics frequently included were selected (Bean et al., 2001; Jackson et al., 2003). However some critical characteristics such as religious belief, ethnic origin- that may create hesitance to respond in Turkish culture were ignored.

In the second part, three subheadings were included, with each containing questions on the same concepts such as culture, gender, country, ethnicity, age, education, religion, country, region. All, none, and others (openended answer) were included as possible answers. The reason was to get data on how the participants perceive diversity in different context. The aim of the first heading was to determine the meaning of diversity for each respondent. The aim of the second heading was to identify diversity factors at play in work settings (teamwork), whereas the focus of the third heading was on diversity factors that dictate social distance.

The third part of the instrument sought to reveal the advantages and disadvantages of team diversity and the advantages of homogeneous groups. In the second and third parts, participants could choose more than one of the categories. The third part was organized by considering the literature on advantages and disadvantages of diversity Cox, 1991; Mor Barak/Cherin/ Berkman, 1998; Knouse/Dansby, 1999; Kersten, 2000; De Meuse/Hostager, 2001

The fourth part consisted of 16 items with a 5-point Likert-type scale ranging from 1 (never or strongly disagree) to 5 (always or strongly agree) depending on the item. Of the 16 items, 15 were adapted from Robert Bean's and Caroline Dillon's Diversity Climate Survey Instrument (Bean et al., 2001). The second author of this paper had contacted to Robert Bean about the instrument via e-mail and encouraged to conduct the survey. The Diversity Climate Survey includes 15 questions about the perceived degrees of respect for the individual, equality of opportunity, openness, trust and social interaction among employees as well as questions about the perceived incidence of unequal treatment, discrimination, conflicts or communication difficulties. The climate questions are divided into three sections as follows: Individual Factors, Work Group Factors and Organizational Factors. There are five questions with a rating choice in each section, respectively (see attached survey for last part statements). The final item that was added by the authors of this paper was related to the degree of tolerance toward diversity and a proverb attributed to Mevlana, a Turkish philosopher: "Take part, no matter who you are, just come in". This is considered as the motto of Turkish culture and it was checked whether participants in the workplace took a similar approach. 


\section{Results}

SPSS version 12.0 was used to analyze the data. Before conducting tests, open-ended questions were classified and recoded. Three items of the diversity climate scale were also recoded because they corresponded to negative statements on the scale. Thus, all the items were included in tests as positive wordings.

Cronbach's alpha coefficient was 0.865 , indicating that the instrument was highly reliable. All items were considered necessary and none were deleted on the basis of reliability results. The mean score was 3.87 (range 3.180-4.680). Mean scores for the items were different, demonstrating that each item was perceived in the same way and that each reveals different characteristics (Hotelling $\mathrm{T}^{2}=1055.997 ; \mathrm{F}=67.700 ; \mathrm{p}<0.001$ ). On the whole, the scale items exhibited additivity $(\mathrm{F}=31.306 ; \mathrm{p}<0.001)$ and the alpha model was congruent $(\mathrm{F}=43.547 ; \mathrm{p}<0.001)$.

Table 2: Meaning of diversity, and refusal factors in team diversity and social diversity $(\%)$

\begin{tabular}{|l|c|c|c|}
\hline & Meaning of diversity & \multicolumn{2}{|c|}{ Refusal factors } \\
\hline & & Team diversity & Social diversity \\
\hline Gender & 8.7 & 2.2 & 8.5 \\
\hline Age & 7.1 & 2.5 & $\mathbf{1 1 . 7}$ \\
\hline Education & $\mathbf{4 6 . 7}$ & $\mathbf{1 8 . 0}$ & $\mathbf{1 2 . 8}$ \\
\hline Religion & 6.8 & 5.7 & $\mathbf{1 5 . 0}$ \\
\hline Ethnicity & 9.8 & 7.4 & $\mathbf{1 7 . 2}$ \\
\hline Disability & 5.5 & 2.7 & 1.9 \\
\hline Culture & $\mathbf{5 4 . 1}$ & $\mathbf{2 3 . 5}$ & $\mathbf{2 2 . 4}$ \\
\hline Region of birth & 4.4 & 4.4 & 8.2 \\
\hline Country & 7.9 & 5.5 & 2.5 \\
\hline All & $\mathbf{2 2 . 7}$ & 3.3 & 5.2 \\
\hline None & 2.5 & $\mathbf{1 8 . 4}$ & $\mathbf{1 1 . 7}$ \\
\hline Others & 4.0 & $\mathbf{2 2 . 6}$ & $\mathbf{1 6 . 7}$ \\
\hline
\end{tabular}

Factors defining diversity and refusal factors in team diversity and social diversity are compared in Table 2 . According to the responses, culture (54.1\%) and education $(46.7 \%)$ were perceived as factors that make one person different from another. Approximately one-fourth of respondents (22.7\%) considered all the factors listed as elements of diversity. In terms of the work setting, 23.5\% were unwilling to work with people from a different culture and $18.0 \%$ would 
Ankara Üniversitesi SBF Dergisi • 65-2

not work with individuals of a different education level. However, $18.4 \%$ of the participants reported that they did not differentiate their colleagues in the workplace. It is noteworthy that $22.6 \%$ of respondents mentioned other factors, which were mainly personality attributes classified by Norman Anderson (Güney, 2000: 257). On the other hand, outside of the work context, culture $(22.4 \%)$, ethnicity $(17.2 \%)$, and religion $(15.0 \%)$ were identified as factors influencing social distance. Other factors $(16.7 \%)$ contributing to social distance were also mainly personality attributes.

Table 3: Diversity team advantage, disadvantages and homogeneous team advantages (in rank order, \%)

\begin{tabular}{|l|r|l|r|l|r|}
\hline $\begin{array}{c}\text { Diversity } \\
\text { disadvantages }\end{array}$ & \% & Diversity advantages & \% & \multicolumn{1}{|c|}{$\begin{array}{c}\text { Homogeneous team } \\
\text { advantages }\end{array}$} & \% \\
\hline Communication & 54.4 & Different perspectives & 78.1 & Communication & 67.8 \\
\hline Conflict & 32.8 & Creativity & 56.6 & Team spirit & 51.9 \\
\hline Decision-making & 27.6 & Flexibility & 11.2 & Decision-making & 33.9 \\
\hline Team spirit & 26.5 & Tolerance & 11.2 & Problem-solving & 30.3 \\
\hline Problem-solving & 19.4 & & & Tolerance & 21.3 \\
\hline Other & 2.5 & & & Creativity & 14.2 \\
\hline & & & & Different perspectives & 13.7 \\
\hline & & & & Flexibility & 13.1 \\
\hline & & & & Other & 2.5 \\
\hline
\end{tabular}

As shown in Table 3, disadvantages identified in the context of team diversity were communication problems (54.4\%) and conflicts $(32.8 \%)$. Conversely, communication $(67.8 \%)$ and team spirit $(51,9)$ were considered the top advantages of a homogeneous team. Differences that team diversity could reveal were noted as different perspectives or ideas (78.1\%) and creativity $(56.6 \%)$. 
Table 4: Comparison of categorical variables for the total diversity climate scores

\begin{tabular}{|l|l|l|l|l|l|}
\hline & & Mean rank & $\mathrm{u}$ & $\mathrm{z}$ & $\mathrm{p} *$ \\
\hline \multirow{2}{*}{ Gender } & Male & 62.44 & & -0.076 & 0.215 \\
\cline { 2 - 3 } & Female & 61.21 & & & \\
\hline \multirow{2}{*}{ Position } & Manager & 64.90 & 10851.500 & -5.769 & $\mathbf{0 . 0 0 0}$ \\
\cline { 2 - 3 } & Non-manager & 59.44 & & & \\
\hline \multirow{2}{*}{ Abroad } & Experience & 63.83 & \multirow{2}{*}{12748.000} & -3.441 & $\mathbf{0 . 0 0 1}$ \\
\cline { 2 - 3 } & No experience & 60.08 & & & \\
\hline & Peryon & 63.04 & \multirow{2}{*}{12284.500} & -3.157 & $\mathbf{0 . 0 0 2}$ \\
\cline { 2 - 3 } & Hotel & 60.08 & & & \\
\hline
\end{tabular}

*Significant at $p<0.05$.

In testing differences between groups, the Mann-Whitney U-test was conducted for pairwise comparisons of gender, position and experience abroad. The disability item was excluded from the analysis since no disabled persons completed the questionnaire.

Differences were found between managers and non-managers in terms of their diversity perceptions according to their total score for the diversity scale. Perceptions of individuals with experience abroad and those not yet been abroad were significantly different. There was also a significant difference between the perception of the Peryon and Hotel groups. Gender had no significant effect on diversity perception, which supports the finding that gender is not an important factor in defining diversity.

Table 5: Comparison of categorical variables for the total diversity climate scores

\begin{tabular}{|l|l|l|l|l|}
\hline & & Mean rank & $\chi^{2}$ & $\mathrm{p}$ \\
\hline Age & $\leq 25$ years & 60.49 & 16.929 & $\mathbf{0 . 0 0 2}$ \\
& 26-35 years & 60.69 & & \\
& 36-45 years & 64.45 & & \\
& 46-55 years & 64.69 & & \\
& $\geq 56$ years & 58.89 & & \\
\hline Education & Primary & 53.92 & 18.959 & $\mathbf{0 . 0 0 2}$ \\
& Secondary & 58.40 & & \\
& Lycee & 61.86 & & \\
& High school & 60.98 & & \\
& University & 63.78 & & \\
\hline Tenure & Postgraduate & 60.88 & & \\
\hline
\end{tabular}


Ankara Üniversitesi SBF Dergisi • 65-2

\begin{tabular}{|c|c|c|c|c|}
\hline (current place) & $\begin{array}{l}1-3 \text { years } \\
4-5 \text { years } \\
\geq 6 \text { years }\end{array}$ & $\begin{array}{l}60.74 \\
60.41 \\
63.08\end{array}$ & & \\
\hline Job no. & $\begin{array}{l}\text { First } \\
\text { Second } \\
\text { Third } \\
\text { Fourth or more }\end{array}$ & $\begin{array}{l}61.30 \\
63.38 \\
61.89 \\
60.83\end{array}$ & 6.739 & 0.081 \\
\hline
\end{tabular}

Groups of more than two variables (i.e., age, education, tenure and workplace number) were compared using the Kruskal-Wallis H-test. As observed in Table 5, age and education had a significant effect $(\mathrm{p}<0.05)$ on diversity perception, whereas the effect of age, tenure and number of jobs was not significant $(\mathrm{p}>0.05)$.

To test the perception of the participants in more detail, each diversity climate variable was analyzed instead of the total scores. Thus, areas that the participants viewed as problematic in the diversity climate were identified, as shown in Tables 5 and 6.

Table 6: Mann-Whitney U-test results for gender, position and experience abroad in relation to each climate variable

\begin{tabular}{|c|c|c|c|c|c|c|}
\hline \multirow[t]{2}{*}{ Variable } & \multirow{2}{*}{$\begin{array}{l}\text { Gender } \\
\mathrm{Z}\end{array}$} & \multirow{2}{*}{$\begin{array}{l}\text { Position } \\
\mathrm{P} \\
\end{array}$} & \multirow{2}{*}{$\begin{array}{l}\text { Abroad } \\
\mathrm{Z}\end{array}$} & \multirow[b]{2}{*}{$\mathrm{p}$} & \multirow[b]{2}{*}{ Z } & \multirow[b]{2}{*}{$\mathrm{p}$} \\
\hline & & & & & & \\
\hline irespect & -0.535 & 0.592 & -5.179 & 0.000 & -3.425 & 0.001 \\
\hline iopportunity & -2.086 & 0.037 & -5.114 & 0.000 & -1.825 & 0.068 \\
\hline iharrasment & -1.464 & 0.143 & -1.237 & 0.216 & -1.479 & 0.139 \\
\hline idiscrimination & -0.843 & 0.399 & -0.221 & 0.825 & -1.084 & 0.278 \\
\hline ifeeling & -1.390 & 0.165 & -4.641 & 0.000 & -3.196 & 0.001 \\
\hline ginvolvement & -1.525 & 0.127 & -4.945 & 0.000 & -1.460 & 0.144 \\
\hline ginclusion & -2.122 & 0.034 & -3.482 & 0.004 & -2.113 & 0.035 \\
\hline grelationproblem & -0.747 & 0.455 & -1.660 & 0.097 & -1.931 & 0.053 \\
\hline gtraining & -1.107 & 0.268 & -2.944 & 0.003 & -1.280 & 0.201 \\
\hline gsocialinclusivity & -1.688 & 0.091 & -4.182 & 0.000 & -2.211 & 0.027 \\
\hline orespect & -0.185 & 0.853 & -2.757 & 0.006 & -0.869 & 0.385 \\
\hline osupport & -1.198 & 0.231 & -3.931 & 0.000 & -2.275 & 0.023 \\
\hline otrust & -0.018 & 0.985 & -4.711 & 0.000 & -2.015 & 0.044 \\
\hline oleadership & -0.743 & 0.458 & -1.828 & 0.068 & -0.567 & 0.571 \\
\hline ochange & -1.917 & 0.055 & -2.924 & 0.003 & -1.719 & 0.086 \\
\hline tolerancephilosophy & -0.417 & 0.677 & -2.428 & 0.015 & -1.484 & 0.138 \\
\hline
\end{tabular}

Significant values are indicated in bold.

Note: Variables beginning with " $i$ " refer individual level; variables beginning with " $g$ " refer group level; variables beginning with "o" refer organizational level. 
The climate variables were analyzed to determine which were influenced by gender, position and experience abroad. Gender was significant for individual opportunity and group inclusion. Position was significant for many of the variables (Table 6).

Age, education, tenure and number of jobs (turnover rate) were tested to investigate which items they influenced. As observed in Table 7, each category had a significant effect on some of the climate variables.

Table 7: Kruskal-Wallis results for age, education and tenure in relation to each climate variable

\begin{tabular}{|c|c|c|c|c|c|c|c|c|}
\hline \multirow[t]{2}{*}{ Variable } & \multicolumn{2}{|c|}{ Age } & \multicolumn{2}{|c|}{ Education } & \multicolumn{2}{|c|}{ Tenure } & \multicolumn{2}{|c|}{ No. of jobs } \\
\hline & $\chi^{2}$ & $\mathrm{p}$ & $\chi^{2}$ & $\mathrm{p}$ & $\chi^{2}$ & $\mathrm{p}$ & $\chi^{2}$ & $\mathrm{p}$ \\
\hline irespect & 26.035 & 0.000 & 19.67 & 0.001 & 14.138 & 0.003 & 10.573 & 0.014 \\
\hline iopportunity & 6.461 & 0.167 & 15.198 & 0.010 & 1.450 & 0.694 & 0.528 & 0.913 \\
\hline iharrasment & 1.574 & 0.814 & 4.266 & 0.512 & 5.762 & 0.124 & 8.743 & 0.033 \\
\hline idiscrimination & 3.161 & 0.531 & 10.947 & 0.052 & 4.590 & 0.204 & 0.655 & 0.884 \\
\hline ifeeling & 33.659 & 0.000 & 15.226 & 0.009 & 15.428 & 0.001 & 1.610 & 0.657 \\
\hline ginvolvement & 7.430 & 0.115 & 2.577 & 0.765 & 1.409 & 0.704 & 6.898 & 0.075 \\
\hline ginclusion & 8.651 & 0.07 & 16.342 & 0.006 & 4.325 & 0.228 & 2.725 & 0.436 \\
\hline grelationproblem & 2.290 & 0.683 & 21.593 & 0.001 & 2.124 & 0.547 & 1.196 & 0.754 \\
\hline gtraining & 14.195 & 0.007 & 1.809 & 0.875 & 13.287 & 0.004 & 4.161 & 0.245 \\
\hline gsocialinclusivity & 7.957 & 0.093 & 3.493 & 0.624 & 2.463 & 0.482 & 2.141 & 0.544 \\
\hline orespect & 1.878 & 0.758 & 11.395 & 0.044 & 3.323 & 0.344 & 3.337 & 0.343 \\
\hline osupport & 7.628 & 0.106 & 18.286 & 0.003 & 4.096 & 0.251 & 4.943 & 0.176 \\
\hline otrust & 9.871 & 0.043 & 8.622 & 0.125 & 5.567 & 0.135 & 7.878 & 0.049 \\
\hline oleadership & 4.067 & 0.397 & 4.549 & 0.473 & 5.853 & 0.119 & 0.601 & 0.896 \\
\hline ochange & 10.577 & 0.032 & 8.419 & 0.135 & 7.424 & 0.060 & 1.746 & 0.627 \\
\hline tolerancephilosophy & 7.446 & 0.114 & 5.410 & 0.368 & 0.376 & 0.945 & 7.564 & 0.056 \\
\hline
\end{tabular}

Note: Significant values are indicated in bold.

In terms of the philosophy of Mevlana, a significant difference was observed between managers and non-managers $(u=14312.500, \quad \mathrm{z}=-2.428$; $\mathrm{p}=0.015)$. The mean for managers (3.58) was greater than for non-managers (3.30). So, this philosophy is not a significant factor in other categories. 


\section{Conclusion}

In this study we investigated the issue of diversity in workplaces in Turkey. In the current era of intense international and multicultural developments in the Turkish marketplace, determining how people in business organizations see "others" is imperative. Efforts in this area will provide business managers with ideas for human resource practices and will help companies to improve their social profile in preparing for global readiness. The study revealed some significant findings regarding diversity in the workplace.

From our analysis, we conclude that people view diversity mainly as cultural and educational differences. Other diversity elements such as age, gender, region, country, ethnicity and religion are also viewed as sources of difference. In the work setting, culture, personality and education are critical factors that influence how people work together. On the other hand, besides culture and personality, ethnicity and religion are critical factors in the social setting that determine personal contacts. The importance of ethnicity and religion as factors in social distance may have been highlighted because of recent developments and discussions in Turkish social and political life. This is particularly true after the breakthrough on secularism and religion-focused groupings, as well as different groups favoring nationalism or separatism on Kurdish issues. The importance of these factors can be expected to increase in 2008. It is noteworthy that important differences in the social context, such as ethnicity and religion, are put aside by individuals in the workplace. Gender difference is not the main factor in organizational and social settings, which is surprising, since discussions in the literature on diversity generally focus on gender issues.

As expected, diversity can lead to communication problems and conflicts, whereas a lack of these problems is seen as the main advantage of a homogeneous group. The expected benefits from diverse groups are alternative opinions and creativity. These are essential reasons for firms to improve diversity in the workplace.

The overall perception of diversity is significantly different between managers and non-managers, between people who have gained experience abroad and those who have not, and between participant groups (Peryon and Hotel). Education and age have a significant influence on the perception of diversity, whereas tenure and the number of job changes do not. Higher education, a management role, and experience abroad lead to a higher positive perception of diversity. Since more Peryon staff members had a higher level of education, more were in a management role and more had experience abroad 
compared to Hotel participants, the significant differences between these two groups are reasonable.

Having a look at diversity through domestic view is the implication of this study for researchers where such attention is getting popular. It is also important for practitioners, managers, researchers and scholars to consider domestic side of diversity to understand what possible attitudes will be toward foreign cultures and their members in a global world.

The limitation of this research is its inclusion of limited number of hotel managers and employees in Bursa, and professional group members of Peryon. Thus, the results can not be generalized, however this research can be seen as an effort to give way to conduct detailed researches on diversity issue in organizations in the future.

\section{References}

ALDERFER, C.P./SMITH, K.K. (1982), "Studying intergroup relations embedded in organizations," Administrative Science Quarterly, 27: 35-65.

ASLAN, M. /VASILYEVA, M. (2003), "Ișyerinde Algılanan Cinsel Tacizin Kültürlerarası Farkı: Türkiye ve Rusya Saha Cumhuriyetinde Bir Uygulama," Paper presented at 11.Ulusal Yonetim Organizasyon Kongresi (Afyon, Turkey): 461-470.

BALI, A.Ş. (2001), Çok Kültürlülük ve Sosyal Adalet- “Öteki” ile Barıș lçinde Yaşamak (Konya: 1. Basım, Çizgi Kitabevi).

BARRY, B./BATEMAN, T.S. (1996), "A Social Trap Analysis of the Management of Diversity," Academy of Management Review, 21/3: 757-790.

BAȘARAN, İ.E. (2000), Örgütsel Davranıș- Insanın Üretim Gücü (Ankara: 3.Yeniden Yazim, Feryal Matbaası).

BEAN, R./SAMMARTINO, A./O'FLYNN, J./LAU, K./NICHOLAS, S. (2001), "Using Diversity Climate Surveys: A Toolkit for Diversity Management," Programme for the Practice of Diversity Management by Department of Immigration and Multicultural Affairs (DIMA) and Australian Centre for International Business (ACIB), Retrieved June 2005 from http://wff2.ecom.unimelb.edu.au/acib/diverse/ducs/using.pdf.

CHATMAN, J.A./POLZER, J.T./BARSADE, S.G./NEALE, M.A. (1998), "Being Different yet Feeling Similar: The Influence of Demographic Composition and Organizational Culture on Work Processes and Outcomes," Administrative Science Quarterly, 43: 749-780.

COMBS, G.M. (2002), "Meeting the LLeadership Challenge of a Diverse and Pluralistic Workplace: Implications of Self-efficacy for Diversity Training," Journal of Leadership \& Organizational Studies, 8/4: 1-16.

COTTE, J./RATNESHWAR, S. (1999), "Juggling and Hopping: What Does it Mean to Work Polychronically?," Journal of Management Psychology, 14/ 3-4: 184-204.

COX, T. Jr. (1991), “Multicultural organization," Academy of Management Executive, 5/2: 34-47.

COX, T. Jr. (1993), Cultural Diversity in Organizations: Theory, Research and Practice (San Francisco: Berrett-Kehler).

DE MEUSE, K.P./HOSTAGER, T.J. (2001), "Developing an Instrument for Measuring Attitudes Toward and Perceptions of Workplace Diversity: An Initial Report," Human Resources Management Quarterly, 12/1: 33-51. 
DREACHSLIN, J.L./SAUNDERS, J.J. Jr. (1999), “Diversity Leadership and Organizational Transformation: Performance Indicators for Health Services Organizations," Journal of Healthcare Management, 44/6: 427-439.

ELY, R.J./THOMAS, D.A. (2001), “Cultural Diversity at Work: The Effects of Diversity Perspectives on Work Processes and Outcomes," Administrative Science Quarterly, 46/2: 229-273.

FRIEDMAN, H.H./AMOO, T. (2002), “Workplace Diversity: The Key to Survival and Growth," Retrieved March 2006 from www. westga.edu/ bquest/2002/diversity.htm.

GÜLGÖZ, S. (2005), “Önyargılar, Türkler ve Diğer Milletler...,” Cumhuriyet Bilim Teknik, 978.

GÜMÜȘ, M. (2009), İșletmelerde Farklılıkların Yönetimi (Bursa: MKM Yayıncılık).

GÜNEY, S. (2000), Davranıș Bilimleri (Ankara: Nobel Yayın Dağıtım).

HICKS-CLARKE, D./ILES, P. (2000), "Climate for diversity and its effects on career and organizational attitudes and perceptions," Personnel Review, 29/3: 324-345.

HON, L.C./BRUNNER, B. (2000), “Diversity Issues and Public Relations," Journal of Public Relations Research, 12/4: 309-340.

JACKSON, S.E./BRETT, J.F./SESSA, V.I./COOPER, D.M./JULIN, J.A./ PEYRONNIN, K. (1991), "Some Differences Make a Difference: Individual Dissimilarity and Group Heterogeneity as Correlates of Recruitment, Promotions, and Turnover," Journal of Applied Psychology, 76/5: 675-689.

JACKSON, S.E./JOSHI, A./ERHARDT, N.L. (2003), "Recent Research on Team and Organizational Diversity: SWOT Analysis and Implications," Journal of Management, 29/6: 801-830.

JOPLIN, J.R.W./DAUS, C.S. (1997), “Challenges of Leading a Diverse Workforce,” The Academy of Management Executive, 11/3: 32-47.

KERSTEN, A. (2000), “Diversity Management-Dialogue, Dialectics and Diversion,” Journal of Organizational Change Management, 13/3: 235-248.

KOSSEK, E.E./ZONIA, S.C. (1993), “Assessing Diversity Climate: A Field Study of Reactions to Employer Efforts to Promote Diversity," Journal of Organizational Behaviour, 14/1: 61-81.

KNOUSE, S.B./DANSBY, M.R. (1999), "Percentage of Work-group Diversity and Work-group Effectiveness," The Journal of Psychology, 133/5: 486-494.

LAURSEN, K./MAHNKE, V./VEJRUP-HANSEN, P. (2004), “Do Differences Make a Difference? The Impact of Human Capital Diversity, Experience and Compensation on Firm Performance in Engineering Consulting", Paper presented at the DRUID Summer Conference on Industrial Dynamics, Innovation and Development, Elsinore, Denmark.

MILLIKEN, F.J./MARTINS, L.L. (1996), "Searching for Common Threads: Understanding the Multiple Effects of Diversity in Organizational Groups," Academy of Management Review, 21/2: 402-433.

MONTEI, M.S./ADAMS, G.A./EGGERS, .M. (1996), "Validity of Scores on the Attitudes Toward Diversity Scale (ATDS)," Educational and Psychological Measurement, 56: 293-303.

MOR BARAK, M. E./CHERIN, D.A./BERKMAN, S. (1998), "Organizational and Personal Dimensions in Diversity Climate," The Journal of Applied Behavioural Science, 34/1: 82-104.

O’FLYNN, J./NICHOLAS, S.,/SAMMARTINO, A./LAU, K./SELALMATZIDIS, L. (2001), "The Business Model for Diversity Management: The Big Picture," Programme for the Practice of Diversity Management by Department of Immigration and Multicultural Affairs (DIMA) and Australian Centre for International Business (ACIB), Retrieved March 2006 from http://wff2.ecom.unimelb.edu.au/acib/diverse/ducs/.pdf.

ÖNEN, K. (2006), “Kimlik Konusu Tartıșmaları,” Cumhuriyet Gazetesi.

SARGUT, A.S. (2001), Kültürlerarası Farklılașma ve Yönetim (Ankara: 2.Baskı, İmge Kitabevi).

SCHNEIDER, B./REICHER, A.E. (1993), “On the Etiology of Climate,” Personnel Psychology, 36/1: 19-39. 
SCHNEIDER, B./GUNNARSON, S.K./NILES-JOLLY, K. (1994), "Creating the Climate and Culture of Success," Organizational Dynamics, 23/1: 17-29.

STRAUS, J.P./CONNERLEY, M.L. / AMMERMANN, P.A. (2003), "The 'Threat Hypothesis': Personality and Attitudes Toward Diversity," The Journal of Applied Behavioral Science, 39/1: 32-52.

TOPRAK, Binnaz et al. (2008), Türkiye'de Farklı Olmak-Din ve Muhafazakarlık Ekseninde Ötekileștirilenler (Araștırma Projesi) (İstanbul: Boğaziçi Üniversitesi Yayınları, Yayın No. 1025).

TRIANDIS, H.C. (2003), "The Future of Workforce Diversity in International Organizations: A Commentary," Applied Psychology: An International Review, 52/3: 486-495.

TSUI, A.S./EGAN, T.D./O'REILLY, C.A. III. (1992), "Being Different: Relational Demography and Organizational Attachment," Administrative Science Quarterly, 37: 549-579.

USLUATA, A. /BAL, E.A. (March 2007), "The Meaning of Diversity in a Turkish Company: An Interview with Mehmet Oner," Business Communication Quarterly, 98-102.

Web URL :

http://web20.s112.typo3server.com

http://www.un.org

http://www.peryon.org.tr

http://www.wfpma.com/turkey.html

http://www.peryon.org.tr/hakkimizda.asp 
